University of Nebraska - Lincoln

DigitalCommons@University of Nebraska - Lincoln

Faculty Publications, Department of Psychology

Psychology, Department of

$1-1987$

\title{
The Effects of Day Care Participation on Parent-Infant Interaction at Home
}

Carolyn P. Edwards

University of Nebraska-Lincoln, cedwards1@unl.edu

Mary Ellin Logue

University of Massachusetts, Amherst

Sandra R. Loehr

University of Massachusetts, Amherst

Sanford B. Roth

University of Massachusetts, Amherst

Follow this and additional works at: https://digitalcommons.unl.edu/psychfacpub

Part of the Education Commons

Edwards, Carolyn P.; Logue, Mary Ellin; Loehr, Sandra R.; and Roth, Sanford B., "The Effects of Day Care Participation on Parent-Infant Interaction at Home" (1987). Faculty Publications, Department of Psychology. 609.

https://digitalcommons.unl.edu/psychfacpub/609

This Article is brought to you for free and open access by the Psychology, Department of at DigitalCommons@University of Nebraska - Lincoln. It has been accepted for inclusion in Faculty Publications, Department of Psychology by an authorized administrator of DigitalCommons@University of Nebraska - Lincoln. 


\title{
The Effects of Day Care Participation on Parent-Infant Interaction at Home
}

\author{
Carolyn Pope Edwards, Ed.D., Mary Ellin Logue, Ed.D., \\ Sandra R. Loehr, M.Ed., and Sanford B. Roth. Ed.D \\ School of Education, University of Massachusetts, Amherst
}

\begin{abstract}
This study assessed how parents who placed their children in a model infant and toddler center were, over time, influenced by three salient features of the center: its child-centered focus, its social orientation, and its support for men in nurturing roles.
\end{abstract}

Supplementary care for very young children by nonfamily members is a growing phenomenon in American society. In 1982, 39\% of mothers with children under age three were employed. Many (31\%) arranged for a nonrelative to care for their child in their own or the caregiver's home, while almost $10 \%$ used center-based care as their principal arrangement. These trends were even higher for well-educated, high income, and full-time working mothers.

Research on infant-toddler care is increasing, ${ }^{2,4}$ but questions with pressing social policy implications remain, e.g., the preventive role of child care services and links between home and other settings in children's lives. ${ }^{12}$ These links may be changing in critical ways today as parents - stressed in their daily lives and isolated from traditional networks - look for new models and supports in their child- rearing roles. ${ }^{1,4}$ Research on the effects of child care requires moving beyond earlier paradigms to an ecological perspective in which families are seen as participants in interconnected settings that directly and indirectly influence the developing child.

This study sought to assess the linkage between home and child care setting for one type of child care: high quality care in a university program. We assume that human behavior is shaped by the physical and social characteristics of the settings in which people spend their time. ${ }^{6,9,15}$ We hypothesized that parents who chose to place their children in a university research and training site would, over time, be influenced by three salient features of this center: its childcentered focus (originating in teachers' professional training); its social orientation (made possible by high adult/child ratio); and its support for men in nurturing roles (evidenced by male staff and interns). 


\section{Sample}

The children were enrolled in the study at ages varying from two to 22 months and were followed for eight months during the 1980-1981 academic year. Center children (ten boys, nine girls) included all but two children in a half-day (20 hours each week) program run by the school of education of a large New England state university. The Noncenter group (matched to the Center group on sex, sibling order, and age within two months) received nonmaternal care a mean of 20.8 hours per week and nonparental care (from babysitters and family day care providers) a mean of 11.2 hours per week. The families were intact, middle class, and primarily college-educated. The Noncenter group was recruited from the center's waiting list and from the town birth list, a newspaper advertisement, and personal contacts. Center and Noncenter parents did not differ in age, education, or employment characteristics but did differ in attitudes toward day care for infants.

\section{Method}

An ethnographic technique called Spot Observation was adapted to examine the children's daily activities and social relations in the main settings in which they received care (parental and nonparental). ${ }^{10,13}$ Observations were conducted in home settings by telephone. The parent or caregiver who picked up the phone observed and reported answers to a standard list of brief questions concerning the identities, whereabouts, major activities, and physical positions of everyone at the moment the phone rang. Observations of the day care center were conducted directly through classroom observation windows. The observer took a mental snapshot of the scene surrounding the child, then recorded the required information.

From October to January (Period 1), 21 Spot Observations of each child were conducted; 21 more were conducted from Feb- ruary to May (Period 2). Each of the seven weekdays was represented six times. Observations were equally divided according to time of day: morning (9:00-11:00), afternoon (3:00-5:00), and evening (5:00-7:00). Participants did not know when observations would occur and subjects were always sampled in random order.

To assess interrater reliability for home observations, one team member telephoned 17 homes while another listened on a phone extension. Independently coded, the forms showed at least 88\% (average $99 \%$ ) agreement on 45 coded categories. To assess reliability at the center, two observers independently collected and coded 28 observations which showed at least $85 \%$ (average 97\%) agreement.

\section{Findings}

The observations were separated into two pools: parent time (child under parental supervision) and caregiver time (teacher, sitter, or family day care provider in charge). The parent time observations were further subdivided into Periods 1 and 2 in order to examine group differences over time. Observations in which children were asleep versus awake differed systematically and the percentage of awake observations varied by group and setting. Only awake observations were included in this analysis.

The left side of Table 1 shows that for parent time observations, differences between the Center and Noncenter families increased over time. During the first half of the study, the groups differed on two measures, but during the second half they differed on ten. The Center parents were higher on play, touching, and holding; more adults tended to be near the child; and the father, in particular, was more frequently present and more involved. The Noncenter parents, in contrast, scored higher on maternal involvement and performing of household chores; the child was more often alone in another room. 
Table 1. Percentage of Children's Awake Observations

\begin{tabular}{|c|c|c|c|c|c|c|c|c|c|}
\hline & \multicolumn{6}{|c|}{$\begin{array}{c}\text { Observations During } \\
\text { Parent Care }\end{array}$} & \multicolumn{3}{|c|}{$\begin{array}{l}\text { Observations During } \\
\text { Caregiver Time }\end{array}$} \\
\hline & \multicolumn{3}{|c|}{ Period 1 (Fall) } & \multicolumn{3}{|c|}{ Period 2 (Spring) } & \multirow[b]{2}{*}{ Center } & \multirow[b]{2}{*}{$\begin{array}{l}\text { Non- } \\
\text { Center }\end{array}$} & \multirow[b]{2}{*}{$\begin{array}{l}\text { Chi } \\
\text { Square }\end{array}$} \\
\hline & Center & $\begin{array}{l}\text { Non- } \\
\text { Center }\end{array}$ & $\begin{array}{c}\text { Chi } \\
\text { Square }\end{array}$ & Center & $\begin{array}{l}\text { Non- } \\
\text { Center }\end{array}$ & $\begin{array}{l}\text { Chi } \\
\text { Square }\end{array}$ & & & \\
\hline \multicolumn{10}{|l|}{ Variables Predicted Higher for Center Group } \\
\hline $\begin{array}{l}\text { Child-Centered Activity by Adults } \\
\text { Nearest adult plays/reads w. child } \\
\text { Nearest adult cares for child }\end{array}$ & $\begin{array}{l}27.2 \% \\
28.3\end{array}$ & $\begin{array}{l}22.6 \% \\
21.2\end{array}$ & $\begin{array}{l}\text { NS } \\
\text { NS }\end{array}$ & $\begin{array}{l}31.0 \% \\
23.2\end{array}$ & $\begin{array}{l}23.1 \% \\
16.9\end{array}$ & $\begin{array}{l}3.0^{+} \\
\mathrm{NS}\end{array}$ & $\begin{array}{l}53.4 \% \\
21.1\end{array}$ & $\begin{array}{l}25.0 \% \\
20.5\end{array}$ & $\begin{array}{l}11.2^{* *} \\
\text { NS }\end{array}$ \\
\hline $\begin{array}{l}\text { Social Closeness } \\
\text { Density: two or more adults } \\
\text { nearby }^{2}\end{array}$ & 30.7 & 24.0 & NS & 34.6 & 25.8 & $3.5^{+}$ & 78.2 & 6.8 & $75.6^{* * *}$ \\
\hline $\begin{array}{l}\text { Density: two or more children } \\
\text { nearby } \\
\text { Nearest adult touching child } \\
\text { Nearest adult holding child }\end{array}$ & $\begin{array}{r}3.5 \\
49.1 \\
25.4\end{array}$ & $\begin{array}{r}2.8 \\
37.8 \\
21.7\end{array}$ & $\begin{array}{l}\text { NS } \\
5.1^{*} \\
\text { NS }\end{array}$ & $\begin{array}{r}4.8 \\
41.7 \\
23.8\end{array}$ & $\begin{array}{r}2.2 \\
21.7 \\
12.9\end{array}$ & $\begin{array}{l}\text { NS } \\
9.2^{* *} \\
7.9^{* *}\end{array}$ & $\begin{array}{l}73.3 \\
35.4 \\
15.9\end{array}$ & $\begin{array}{r}40.9 \\
18.2 \\
9.1\end{array}$ & $\begin{array}{l}16.3^{* * *} \\
4.7 \\
\text { NS }\end{array}$ \\
\hline $\begin{array}{l}\text { Adult Male Involvement } \\
\text { One or more men nearby } \\
\text { Father's level of involvement }{ }^{3} \\
\text { Primary level } \\
\text { Secondary level } \\
\text { Tertiary level }\end{array}$ & $\begin{array}{l}18.5 \\
46.2 \\
35.3\end{array}$ & $\left.\begin{array}{l}14.3 \\
44.7 \\
41.0\end{array}\right\}$ & NS & $\begin{array}{l}16.1 \\
50.6 \\
33.3\end{array}$ & $\left.\begin{array}{l}11.5 \\
42.2 \\
46.2\end{array}\right\}$ & $8.8^{* *}$ & 40.4 & 0.0 & $26.0^{* * *}$ \\
\hline Variables Predicted Higher for Noncente & er Group & & & & & & & & \\
\hline $\begin{array}{l}\text { Adult-Centered Activity by Adults } \\
\text { Nearest adult performs } \\
\text { household chore }\end{array}$ & 22.0 & 29.5 & $2.8^{+}$ & 22.0 & 30.7 & $3.6^{+}$ & 4.3 & 31.8 & $28.4^{* * *}$ \\
\hline $\begin{array}{l}\text { Nearest adult rests, eats, } \\
\text { studies, etc, }\end{array}$ & 22.5 & 26.7 & NS & 23.8 & 29.3 & NS & 21.2 & 22.7 & NS \\
\hline Social Distance & & & & & & & & & \\
\hline $\begin{array}{l}\text { Nearest adult not in same room } \\
\text { Child held in restraining device } \\
\text { Child amuses self }^{5}\end{array}$ & $\begin{array}{r}8.7 \\
6.9 \\
19.1\end{array}$ & $\begin{array}{r}12.0 \\
9.7 \\
24.4\end{array}$ & $\begin{array}{l}\text { NS } \\
\text { NS } \\
\text { NS }\end{array}$ & $\begin{array}{l}10.7 \\
11.3 \\
16.1\end{array}$ & $\begin{array}{r}20.9 \\
9.8 \\
23.6\end{array}$ & $\begin{array}{l}7.2^{* *} \\
\mathrm{NS} \\
3.3^{+}\end{array}$ & $\begin{array}{l}5.0 \\
3.1 \\
9.9\end{array}$ & $\begin{array}{l}34.1 \\
11.4 \\
18.2\end{array}$ & $\begin{array}{l}29.4^{* * *} \\
5.1^{*} \\
\text { NS }\end{array}$ \\
\hline $\begin{array}{l}\text { Adult Female Involvement } \\
\text { Mother's level of involvement }{ }^{3} \\
\text { Primary level } \\
\text { Secondary level } \\
\text { Tertiary level }\end{array}$ & $\begin{array}{r}41.7 \\
49.6 \\
8.7\end{array}$ & $\left.\begin{array}{l}32.2 \\
56.2 \\
11.5\end{array}\right\}$ & NS & $\begin{array}{l}31.6 \\
52.4 \\
16.1\end{array}$ & $\left.\begin{array}{r}29.7 \\
60.4 \\
9.8\end{array}\right\}$ & $4.13^{+}$ & & & \\
\hline Total Number of Observations & 173 & 217 & & 168 & 225 & & 161 & 44 & \\
\hline
\end{tabular}

1. For all Chi Square tests, $d f=1$, except for Father's and Mother's Levels of Involvement, where $d f=2$. Tests of significance are two-tailed: ${ }^{+} \mathrm{p}<.10 ;{ }^{*} \mathrm{p}<.05 ;{ }^{* *} \mathrm{p}<.01 ;{ }^{* * *} \mathrm{p}<.001$

2. Nearby is defined as same room (for home observations) or same section of classroom (for center observations).

3. Following LaRossa and LaRossa, ${ }^{7}$ parent level of involvement is defined in terms of parent's major (focal) activity at moment of observation, Primary level = caring for, holding, playing, or socializing with child, Secondary level $=$ present (hence available) but engaged in a non-child centered focal activity. Tertiary level absent, hence unavailable to child.

4. A restraining device is something child cannot get out of by itself, e.g., crib, playpen, highchair, infant seat.

5. Amusing self includes play and idle activity where no one is interacting with child or in the same activity. 
Further, as the right side of Table 1 indicates, these parent time group differences mirror fairly closely those in caregiver time, though they are not as extreme in magnitude. The two types of caregiver settings differed dramatically: the center showed much higher levels of adult play and touching of children, social density, and presence of caregiving men.

The findings thus support the hypotheses (as do other data from home environment assessments, monthly questionnaires, and videotaped observations.) $)^{5,8}$ However, because the groups differed on two Spot Observation measures during Period 1, caution is required in interpretation. We suggest that participation in the day care program may have amplified rather than caused changes in parental behavior. Participation may have heightened awareness of values of child-centeredness, social orientation, and paternal involvement and strengthened preexisting differences between the Center and Noncenter families' behavior at home.

Certainly, the findings indicate the importance of closer study of the people, activities, roles and social relations in different kinds of caregiving settings in order to understand better their impact on the people they serve. Though the sample was small and the focus limited to one model center, the findings demonstrate that we can improve our study of the effects of day care by doing research that specifies the social dimensions of the day care program in question, cuts across setting boundaries, and examines changes in both parent and child behavior.

\section{References}

1. Belle. D., ed. 1982. Lives in Stress. Sage Publications, Beverly Hills, Calif.

2. Belsky. J. \& Steinberg. D. 1978. The effects of daycare: A critical review. Child Devlpm. 49:929-949.

3. Bronfenbrenner, U. 1979. The Ecology of Human Development. Harvard University Press. Cambridge. Mass.
4. Clarke-Stewart, A. \& Fein, G. G. 1983. Early childhood programs. In Handbook of Child Psychology, Vol. II. Infancy and Developmental Psychobiology. M. M. Haith and J. J. Campos, eds. John Wiley, New York.

5. Edwards, C. P. et al. 1986. The influence of model infant-toddler group care on parentchild interaction at home. Early Child. Res. Quart. 1(4):317-332.

6. Edwards, C. P. \& Whiting, B. B. 1980. Differential socialization of girls and boys in the light of cross-cultural research. In Anthropological Perspectives on Child Development. C. M. Super and S. Harkness. eds. Jossey-Bass, San Francisco.

7. La Rossa., R. \& La Rossa, M. M. 1981. Transition to Parenthood: How Infants Change Families. Sage Publications, Beverly Hills. Calif.

8. Logue. M. E. 1984. Quality day care for infants and toddlers: Effects on parent-child interaction. Unpublished doctoral dissertation, University of Massachusetts-Amherst.

9. MacRae, J. W. \& Herbert-Jackson, E. 1976. Are behavioral effects of day care program specific? Devlpm. Psycho!. 12:269-270.

10. Munroe, R. H. \& Munroe, R. L 1971. Household density and infant care in an East African Society. J. Soc. Psychol, 83:3-13.

11. O'Connell, M. \& Rogers, C. C. 1983. Child care arrangements for working mothers: June 1982. (Current Population Reports, Series P-23, No. 129). U.S. Government Printing Office, Washington, D.C.

12. Phillips, D. 1984. Day care: Promoting collaboration between research and policy making. 1. Appl. Devlpm. Psychol. 5:91-113.

13. Rogoff, B. 1978. Spot observation: An introduction and examination. Quart. News. Inst. Comp. Hum. Devlpm. 2:21-26.

14. Weinraub, M., \& Wolf, B. 1983. Effects of stress and social supports on mother-child interaction in single and two-parent families. Child Devlpm. 54: 1297-1311.

15. Whiting, B. B. \& Edwards, C. P. The Company They Keep: The Effect of Age, Gender and Culture on Social Behavior of Children Aged 2-10. Harvard University Press. Cambridge. (in press) 